TURIZAM

Volume 14 , Issue 1

13-21 (2010)

\title{
Promotion as a Tool in Sustaining the Destination Marketing Activities
}

\author{
Ivo Mulec* \\ Received: November 2009| Accepted: March 2010
}

\begin{abstract}
Promoting the tourism destination in the right and best possible way is today one of vital marketing activities of all Destination Management Organisations. Only successful promotion can entice and attract potential travellers to visit the destination. The number of new destinations is increasing every year and some of them are quite similar. Market segmentation is one of the starting points for devising marketing strategy. Only by presenting the destination to the right segment of potential clients in the right way will a destination maximise the effectiveness of its marketing and promotion. Tourism destination marketers will continue to face considearble challenges in the future: they will have to take account of the needs, wants and expectations of more mature and knowledgeable customers, and the corresponding need for more up-to-date and reliable information upon which to base decision-making. In the future only marketing which includes collaborative dimensions will meet its objectives fully.
\end{abstract}

Key Words: destination marketing, promotion activities, branding, market segmentation.

\section{Introduction}

Tourism is highly complex, multi-sectoral industry where no single organisation provides or has control over the entire tourism product. Successful delivery of the wider tourism product is dependent on close working relationship, interdependencies and interactions with numerous other stakeholders, enabling the tourism organisation to provide a seamless experience for its customers (Fyall, Garrod, 2005).

Lumsden (I997) suggests that: "Tourism marketing is the managerial process of anticipating and satisfying existing and potential visitor wants more effectively than competitive suppliers or destinations. The management of exchange is driven by profit, community gain, or both; either way long-term success depends on a satisfactory interaction between con-

* Faculty of Sciences, Department of Geography, Tourism and Hotel Management, Trg Dositeja Obradovića 3 , 21000 Novi Sad, Srbija; ivo.mulec@dgt.uns.ac.rs 
sumer and supplier. It also means securing environmental and societal needs as well as core consumer satisfaction.

With tourism being increasingly recognised as a key economic opportunity around the world competition among countries and regions for a share of global tourism expenditure is increasing by the day. Potential tourists are faced with a wide range of holiday and business travel choices. To be recognised and to attract their rightful share of the global tourism market it is of critical importance for destinations to establish a recognised and valued tourism position and brand image in the market. There are three broad approaches companies or destinations can follow to establish an advantage over competitors, namely:

- cost leadership: can be achieved by constantly controlling and reducing costs and improving efficiency of operations, thereby out-priceing competitors,

- focus: means becoming specialists in a very focused area of activity,

- differentiation: destination should offer clients a product, service or experience that has a unique value and is different to those alternatives offered by competitors.

While consumer choices of transport modes and booking channels are increasingly affected by cost, their choices of destinations and experiences are increasingly affected by differentiated product. Consumers will consider how destinations are tailored to their needs and how unique these are in relation to other destinations and experiences (WTO, 2007b).

\section{Differentiating the Destination}

Destinations must also establish a competitive advantage to out-compete other destinations. In the words of Jack Trout, the originator of the positioning concept: "Competition is not a battle of products or services, it is a battle of perceptions in the costumer's mind". Destination may offer the best products and experiences, but unless it is able to create the perception in the minds of potential travellers that it offers something different, better and more appealing than other destinations it may not be in a position to convince travellers to visit.

The key to differentiating the destination is finding a Unique Selling Proposition (USP) and promoting this so as to "own" a unique and valuable tourism attribute(s) in the minds of the current and potential customers. Customer decisions are increasingly influenced by emotional reactions and triggers. In the tourism marketplace, what persuades potential tourists to visit and return to one place instead of another is whether they have empathy with the destination and its values. If the destination does not have a USP, another option is to group together or package similar products to develop a Special Selling Propositon (SSP). The USP is increasingly becoming the Unique Emotional Proposition (UEP) (WTO, 2007b).

\section{Destination Branding}

The destination brand communicates and signals the competitive positioning. A brand could be defined as a unique combination of product characteristics and added values, both tangible and non-tangible. The brand is not only a trademark (logo or icon), but an experience and image that signals a value system and positioning. It is a promise of an experience that the visitor can expect from the destination. A successful destination brand depends upon a number of key factors including: 
- Brand credibility. The brand promises the costumer a particular value and experience and thus automatically creates an expectation. The experience has to live up to the expectation created for the destination to retain a positive image.

- Deliverable. One of the golden rules of branding is never to over-promise and underdeliver. Brand's designs should be tested to ensure effective, on-the-ground delivery of the brand promise.

- Differentiating. Destinations have to avoid the "me too" trap at all costs. The brand should signal the differentiated positioning and not try to emulate other successful designs or strategies.

- Conveying powerful ideas. Branding is all about the hearts and minds of customers and destinations brands will only be truly successful if they convey concepts, values and destination personality traits that speak powerfully to the mind of the marketplace.

- Enthusing for trade partners. The Destination Management Organisations alone will not be able to roll out and communicate the brand proposition. In successful destinations the private sector is the driver of tourism, under government destination leadership. A winning brand should be strongly endorsed and used by the private sector in the destination.

- Resonating with the consumer. Even an award-winning, creative brand design will not be truly successful unless the brand resonates with the customers, encouraging them to visit and converting "lookers" to "bookers".

To develop a successful brand, destinations initially need to fully understand their targeted customer. A destination may have many different experiences and products to offer, each of which will appeal to different markets. The branding process should focus attention on their key target markets. Therefore research is required to fully identify and understand the primary target markets. In the past, market research has focused on finding out what visitor wants and not finding out why? The destination can get ahead of its competitors if it finds out why, by understanding the emotional factors that determine the preferences of its potential visitors. Before embarking on a brand building process it is important for the destination managers to clearly establish a strategic direction on an inspiring future vision on what basis will the destination differentiate itself from its competitors and obtain a fundamental market positioning. In the process of building the brand there are five key phases:

- image investigation

- brand identity development

- brand design

- brand launch and communication

- brand management.

For the brand to be authentic and deliver on its promise the local community and the stakeholders should believe in it and live it. It is a well-known fact that our best brand champions are our citizens, but they could also be our worst enemies, especially if they do not subscribe to brand essence. A special effort is required to communicate and advocate the brand internally. One of the most important vehicles for internalising the brand is to capacitate and enthuse leadership figures to be brand ambassadors and infuse the brand values within the broader society (WTO, 2007b). 


\section{Market Segmentation}

New destinations appear every year. To have any chance of standing out in a busy marketplace, destinations must be single-minded on focusing on those people who they are most likely to be able to attract and who are most likely to purchase a destination's tourism goods and services. Market segmentation is the starting point for devising a marketing strategy and is a process which categorises people into groups where they share certain definable characteristics. There are several reasons to segment a market:

- Only a small percentage of the world's population takes an international trip in any one year.

- Demand for tourism goods and services is not equally distributed throughout a population.

- Minorities within a population are often likely to consume a disproportionately high volume of tourism product.

- It is necessary to develop the product according to the customer's needs, wants and desires.

- Segmentation helps inform which marketing channels and media are the right ones.

The key to effective target marketing is to:

- Identify groups of people (segments) who are, or will be, in the market for an international trip.

- Decide whether these are the people who, if they visited, would help fulfil the destination's tourism objectives.

- Establish whether the destination has the appropriate products and services to meet their needs.

- Establish their motivations/triggers, buying habits, etc.

- Persuade them to visit using appropriate and targeted marketing messages and channels.

- Evaluate and review the impact of the marketing on the segments that have been targeted (Weaver, Lawton, 2006).

\section{Information Sources for Segmentation}

For most National Tourist Organisation, the foundation for good segmentation is based on the collection of inbound tourism statistical data. Tourism visitor surveys would appear to provide the most fruitful source of identifying current tourism segments that visit the host destination. The most common factors in statistical collection and analysis identified by NTOs are:

- activities undertaken (cycling, hiking, golf, etc),

- booking mechanism (internet, travel agent),

- cohort (with whom they travel),

- demographic data (age, occupation, income, education, family, etc)

- group/party size,

- length of stay,

- motivations (recreation, culture, adventure, sun-seeking, etc),

- origin country/place of residence, 
- other countries considered for a visit (i.e. information about competitors),

- purpose of visit (business, VFR, leisure, education, special events, etc),

- repeat or first time visitor

- sources of information when planning to visit a country,

- spending (by category: accomodation, travel, etc),

- transport into country (air, road, sea, rail),

- transport used while in country

- travel dates (by month to assess seasonal variations),

- trip type (independant or package),

- type of accomodation used. (WTO, 2007a).

\section{Identifying Segments}

Once an NTO is in possession of the basic statistical and qualitative data required to disaggregate its source market(s), it is in a position to begin a process of segmentation, which means identifying those groups of customers within a market(s) that share a range of common characteristics and selecting those that it wishes to target. Having identified a range of segments, $\mathrm{NTO}(\mathrm{s})$ are faced with the challenge of deciding which of these offer the best prospects for contributing to the tourism objectives of their destinations. To do this, some $\mathrm{NTO}(\mathrm{s})$ use a range of factors to compare the relative attractiveness of segments. Some of the factors most commonly used as a basis for comparing segments are:

- access to the product,

- accomodation capacity,

- awareness and image of the destination,

- carrier capacity,

- income and education levels,

- market share,

- media usage and availability of promotional opportunities,

- regional spread,

- seasonal spread,

- value/spend (current and forecast),

- visits (current and forecast).

Once target markets are selected, NTOs go about marketing to these markets. Some run campaigns/activities aimed at similar segments in different markets. Many NTOs rely heavily upon third parties to advise them on appropriate communication channels and imagery/ messages with which to reach targeted segments. These parties can be: PR agencies, travel writers/journalists, marketing experts, on-territory NTO staff, research agencies, tour operators, trade publications, especially for niche segments, competitor analyses, consumer exhibitions/shows, desk research, evaluation study results...etc (WTO, 2007a). 


\section{Segmentation Methodologies}

Some of the most frequently used segmentations methodologies are:

- Socio-demographic Segmentation: is the earliest and one of the most useful forms of tourist segmentation. It may include gender, age, family life cycle, income, occupational status, education, nationality and geographic location.

- Purpose of trip Segmetation: is unique to tourism. Visitors are differentiated by the main reasons for which they are taking the trip (holiday or leisure, business, education, VFR, etc).

- Visiting friends and relatives Segmentation (VFR): In the last ten years this segmentation has been radically re-assessed and is now seen as a major source of international tourism revenue and is set to increase due to the radical population shifts affecting the modern world.

- "First time" versus "Repeat visitors'" Segmentation: The first time visitor comes to a destination with no first-hand experience, while the repeat visitor may have considerable knowledge based on many previous trips.

- Benefit segmentation may be defined as a process of distinguising and defining the principal benefits sought by visitor market segments to a destination.

- Activity Segmentation involves identifying the range of activities engaged in by visitors to a destination.

- Motivation Segmentation: Tourism motivation may be defined as a drive that propel people to travel. The positive aspects of motivation have been described as pull factors, and the negative ones driving people away from their environment as push factors.

- Lifestyle Segmentation was widely adopted in tourism in the last decade in order to provide a more holistic understanding of tourists.

- Niche Market Segmentation: a niche market is traditionally a small market, composed of tourists with similar, special tastes, that the destination is uniquely or particularly qualified to attract and serve.

- Geo-demographic Segmentation is a variant of lifestyle segmentation that explores the profile, behaviour and attitudes of target populations.

- Price Segmentation: tourism consumption is both price and income sensitive. Price is a dangerous dimention to emphasise for NTOs in positioning a destination. Price segmentation is normally a short term measure linked to competitive conditions or crisis management where cutting the price may be an incentive to win back a visitor base.

- Media Audience Segmentation involves deciding which publications, broadcast programmes or other advertising media have an audience whose profiles approximate to those of the market for the destination

- Internet Segmentation: internet usage is an increasingly important element in many tourism decisions, but one that varies greatly among people of different nationalities, age groups and travel tastes.

- Business-to-Business Segmentation: this segmentation is particularly important in situations where the end-user (visitor) is not necessarily the decision-maker, such as organizations looking to arrange international conferences, companies arranging training and incentive programmes.

- No Segmentation: for NTO planners to adopt such a strategy would mean that they either believe that their destination appeals to everyone or alternatively, that they have no idea whom it might attract (WTO, 2007a). 


\section{What about Marketing Trends and Promotion of Vojvodina?}

To our knowledge, no significant market research has been undertaken in Vojvodina so far by the responsible authorities or by the NTO to understand the customers' needs and wants and to determine the preferences of its potential visitors. The author of this paper designed a short questionnaire to interview the tourism experts during the Fitur, International Tourism Trade Fair in Madrid. The study was conducted between 20 January - 22 January 2010 during the Fitur exibition intended for experts and professionals. The respondents, 45 in total, are structured as follows: 29 work in tourist agencies (wholesale and retail), II in hotels, 2 in transportation companies and 3 in public administration. After a short written introduction of the Tourist destination Vojvodina, ten questions were asked in order to understand whether Vojvodina is known on the Spanish market and among professionals involved in tourism. Only 6 out of 39 have been to Serbia, and only 2 out of 45 have been to Vojvodina. Thirty-two answered that Vojvodina, as part of Serbia, was a peaceful and stable country, 8 said it was not, and 5 had no idea about it. Apart from that, 38 of them answered that Vojvodina was a safe country for foreign tourists to visit, 3 said it was not and 4 had no idea. Only Io thought that the image of Vojvodina as a part of Serbia in Spain was positive, 23 thought it was negative and $\mathrm{I} 2$ had no idea. As few as 8 respondents presumed that Vojvodina was an attractive and interesting destination, good value for money, I2 said it was not and 25 had no idea about it. Only 2 answered that Vojvodina was known in Spain as a tourist destination, 29 answered that it is little known and I4 said that it was not known at all. When the experts were asked what could be done to promote Vojvodina as a tourist destination in Spain (as several answers were possible), the majority of them answered that the FAM trips should be organised for travel agents and travel journalists, second came promotion in different media, third workshops and special presentations, fourth press conferences on tourist fairs and trades and as the fifth possibility on-line consultations were recommended. When they were asked them if they would like to come and visit Vojvodina themselves, 42 said yes, noone said no and 3 did not know the answer. The same number, i.e. 42, said that they would send their clients to Vojvodina and 3 were not sure about it. These answers clearly show that Vojvodina has no name is Spain and is almost unknown to the Spanish tour operators and agents, let alone the potential tourists. Almost everybody agreed that more promotion was needed and in spite of the fact that the image is not very positive, there is a will and desire to discover this new destination. The authorities should, therefore, treat the Spanish market carefully and professionally.

Besides the lack of vision, there is no clearly established strategic direction in marketing. We can hardly talk about branding. Vojvodina is not even placed on the tourist maps of Central and Eastern Europe, and as a result, its image is not present in the minds of western tourists. A strong and meaningful brand has to be built presenting its unique selling proposition - its ethnic mosaic of people: Vojvodina is Europe in miniature. There is no other destination in the whole Europe with such a great variety of ethnic groups as Vojvodina. Another strong and appealing fact on which its brand should be built is their peaceful coexistence and living in harmony which should serve as a model for the rest of the Balkan regions and countries.

First of all, a list of all the existing destination's products should be compiled as well as a list of all the potential products that should be developed in the near future, especially the products which will differentiate the destination from similar destinations in a highly competitive market. In order to be able to make a comprehensive and good segmentation 
of potential clients, more appropriate inbound tourism statistical data are needed. The most common factors in the existing statistical collection and analysis identified so far are limited mainly to the socio-demographic data, such as: country of origin, length of stay, number of tourists and number of nights spent in the destination and travel dates. Many more factors need to be collected, such as motivations, activities undertaken, spending patterns, etc, in order to have a wider base for a comprehensive market segmentation and eventually for launching different marketing activities.

The current marketing activities led by the NTO are limited to printing catalogues about the tourist offer and actual products available on the market and participating in trade shows and trade fairs around Europe which are selected on the basis of the past experience and convenience instead of following the latest marketing trends in the world. Their promotion remains focused on what 'the destination has to offer' and continue to use mass marketing techniques more suited to the passive customer, forgetting that the modern customers are now highly active partners in the marketing process. It is now the customers who can decide how and by means of what process they access their travel and tourism information and how and by means of what process they access and purchase their travel and tourism arrangements.

Research regarding different types of segmetation should be done, especially that dedicated to business-to-business, lifestyle, niche market, motivations, activities, VFR and purpose-of-trip segmentations. The price segmentation should also be taken into consideration. New, potential destinations, such as Vojvodina, should launch themselves into highly competitive international markets by offering professional services at excellent prices which present high value for money. For the destination marketing in Vojvodina to be effective and successful, it is clear that the NTO needs to bring all individual partners together to collaborate rather than compete, and to pool resources towards developing and integrating the marketing mix and delivery system. Presuming that Vojvodina is still in the Exploration Phase of a Destination Life Cycle from the point of view of Western societies, it is between the Involvement and Development Phases for the surrounding markets of ex-Yugoslav republics. It should, therefore, focus its primary marketing activities on these vital markets first and only after having built a strong brand should its promotion be launched to other markets, as a very special destination within Cental and Eastern Europe.

\section{Conclusion}

Traditional marketing approaches are not sufficient any more to satisfy modern, complex and dynamic tourist demands. Strong partnerships between different stakeholders, especially between private and public sectors, are necessary in order to be successful, competitive and to achieve its desired market share in the market where new destinations appear every day. The segmentation of customers and markets is an essential ingredient of marketing effectiveness and should be taken into consideration before targeting the potential visitors. Only by targeting the segmented customers will a destination maximize the effectiveness of its marketing and promotion. Using the latest marketing trends in a very professional way will make the destination Vojvodna pass from a potential to a developed tourist destination. 


\section{References}

Fyall, A., Garrod, B. (2005). Tourism Marketing, A Collaborative Approach, Aspects of Tourism: I8, Cromwell Press, Great Britain.

Lumsdon, L. (1997). Tourism Marketing, International Thomson Business Press, London. Weaver, D., Lawton, L. (2006). Tourism Management, $3^{\text {rd }}$ edition, John Willey \& Sons, Autralia.

World Tourism Organization (2007a). Handbook on Tourism Market Segmentation, Maximising Marketing Effectiveness, Ist printing, Madrid, Spain.

World Tourism Organization (2007b). A Practical Guide to Tourism Destination Management, $\mathrm{I}^{\text {st }}$ printing, Madrid, Spain.

www.serbia-tourism.org

www.vojvodinaonline.com 